valuable information. And my object in addressing you now is to invite discussion on the suggestion, in the hope that it may be taken up by scientific men in a position to prosecute the inquiry. I hope too, some of the readers of Nature, engaged in kindred studies, will give us the benefit of their experience and the results of any observations calculated to throw light upon it.

T. L. PatTerson.

Greenock, April I7.

\section{Megalithic Folk-lore.}

As I understand that many investigators have come to the conclusion that there are no traces of Dravido-Tibetan races to be found west of Persia, permit me to point out a fact which may not have been brought to their attention.

I have been in Asam now thirty-two years, and during that time the province, and part of Bengal, has been swept (suddenly) from end to end, by a severe scare, which folk at home would find it difficult to understand. It was similar in each case, and to the effect that the Queen wanted five children's heads from each village.

Our Bengali coolies nearly went frantic, in many factories demanding axes and daus (knives) to defend their families. In my own case they implored me to let them put their wives and children on the tea-leaf lofts, while they would guard them at night. In another factory all the doors in the lines were barricaded; or at still another, all were kept wide open so that at the first scream at night all could at once rush out and hide $n$ the jungle.

The state of tension for a week was awful, and of course the Iudicrous now and then came in. Two of my near neighbours, freshly out and bent on snipe, happened one morning to emerge from the jungle, muddy and with guns, among the women-folk at work, who all had their children with them for safety.

For the instant they were taken for the child-stealers, and the stampede and shrieks were something awful.

At one place I found an Asamese village deserted, not a soul left-all in hiding, no doubt.

It was quite useless to argue with the common folk, and my educated Babu even half believed it, for on my explaining the absurdity of it all, he simply answered, "Perhaps, sir, it is too foolish."

After a lot of trouble and correspondence, it turned out that the rumour (believed by all) was that the heads were wanted to put under the foundation of the piers for the Gorai bridge. There must be hundreds of Europeans now at home who can corrolorate this.

And now to the point. It was a custom among the Kasias, $\mathrm{I}$ am told, to sacrifice a victim by putting him in the hole if great difficulty was experienced in raising any of the huge monoliths, and the same custom existed in Polynesia when raising the great posts of Maræ, or large communal houses.

But all over Chota Nagpur, Megalithic remains are common, and our coolies are mostly from thence.

Here then, I take it, we have fairly good evidence that one at least of the "Megalithic" races preserve vividly the folk-lore of past ages. Have we anything like this in European races in re these remains of prehistoric times?

That the building of houses on piles is essentially an Asiatic race custom, I need hardly point out, and that the villages in the Swiss lakes are on the same pattern anthropologists will allow.

It may not be so well known that the long communal houses still seen (as a survival) in Italy (Campagna) are on precisely the same pattern as those among most of our Naga, and among Dyaks

Add to this, that the prehistoric remains of North Europe are like the present Lapps in character, and it seems not impossible or even unlikely that the races who erected the Megalithic remains in Europe and North Africa, may be allied to those among whom the traditions are yet so vividly remembered.

Sibsagar, Asam, March 27.

$$
\text { S. E. PEal. }
$$

\section{The Glacial Drift in Ireland.}

Since the publication of Prof. G. A. J. Cole's letter in NATURE (vol. xlvii. p. 464), in which he records the discovery of pebbles of the Ailsa Craig Riebeckite-eurite from the drift gravels on Killiney strand, numerous observers have noted its occurrence in several places along the east coast of Ireland, but hitherto, I believe, not further south than Greystones, Co.
Wicklow. Owing to the special interest of this rock, both to glacial observers and petrographers, it may be worth mentioning that two weeks ago I found one small pebble (about $3 \mathrm{c} . \mathrm{m}$. square) of the rock on the shore of Tramore Bay, Co. Waterford, nearly 80 miles further south than the previously mentioned locality, and 230 miles from Ailsa Craig.

Royal College of Science, Dublin, April 20.

\section{The Bright Meteor of April 12.}

THIs meteor was visible overhead at Dunstable, Beds., precisely at the time mentioned by A. G. Tansley (p. 58I). I had just started one of my sons to London by the 8.5 p.m. train, and I saw the meteor sail slowly across the sky from north-west to south-east, directly the train had started. The nucleus as seen here was brilliant white and yellow-white with a bright yellowwhite train. The train formed an equilateral triangle, the nucleus being in one angle in front. I did not see the train in the form of sparks; but as light. Before it died away, bcth nucleus and train became bright crimson and an equally brilliant blue. There was no explosion heard by me.

Dunstable. WORTHINGTON G. SMITH.

\section{Remarkable Sounds.}

THE following passage in a Chinese itinerary of Central Asia -Chun Yuen's "Si-yih-kien-wan-luh," I777 (British Museum, No. I 527 I, b. 14), tom. vii. fol. 13, b.-appears to describe the icy sounds similar to what Major Head observed in North America (see p. 78, ante) :-

"Muh-sih-urh-tah-fan (= Muzart), that is Ice Mountain", is situated between Ili and Ushi. ... In case that one happens to be travelling there close to sunset, he should choose a rock of moderate thickness and lay down on it. ${ }^{2}$ In solitary night then, he would hear the sounds, now like those of gongs and bells, and now like those of strings and pipes, which disturb ears through the night : these are produced by multifarious noises coming from the cracking ice." KUMAGUSU MINAKATA.

April 9.

\section{THE ROYAL OBSERVATORY, EDINBURGH.}

THE new Edinburgh Royal Observatory, which was formally opened by the Secretary for Scotland on the 7 th inst., is situated on Blackford Hill, some two and a half miles due south of the centre of the city, in a public park, of which about three acres have been transferred to the Crown by the Edinburgh Town Council. The centre of the observatory is about 440 feet above the level of the sea. The name of Blackford Hill will suggest to many readers the lines from "Marmion":

Blackford ! on whose uncultured breast

Among the broom, and thorn, and whin,

A truant-boy, I sought the nest,

Or listed, as I lay at rest,

While rose, on breezes thin,

The murmur of the city crowd,

And, from his steeple jangling loud, Saint Giles's mingling din.

The main building is T-shaped, with a tower for the 24 inch reflector, removed from Calton Hill, at the west end, and a somewhat larger tower for the 15 -inch Dunecht refractor at the east end. The clear length of the platform above the rooms connecting these towers is IIO feet. The stem of the $T$ is built in three stories. In the basement are the gas engine and dynamo, storage cells and primary batteries, the heating apparatus and a bookstore; while above the library and adjoining rooms is a room 66 feet by 23 feet, with its floor on a level with the platform already mentioned.

This room, which ranges exactly north and south, is intended for optical experiments and spectroscopic

1 In Prejevalsky's "From Kulja, across the Tian-shan to Lob-nor," London, 1879 , foot-note, p. $\mathbf{1 7 7}$, the word Muzart, or Mussart, is stated to mean Snuwy.

The old Chinese pilgrim, Hwen-tsang, who followed this same route observed that the travellers passing thereby must sleep on the ice (Schuyler "Turkestan," London, i 876 , vol. i. p. 39I). 